\title{
Business in times of crisis: A strategic update during COVID-19
}

\author{
F. Faidal \\ Diploma School of Entrepreneurship, Faculty of Economics and Business, \\ University of Trunojoyo Madura, Indonesia
}

\begin{abstract}
We report on turning policymakers' attention to saving people's lives. At the same time, the pandemic crisis is threatening the survival of firms on a global scale, with potentially devastating societal and economic outcomes by novel exogenous shocks, it is shocking transcends past experiences and the implications for SMEs. Companies must innovate and adapt because failing to respond fast could result in great losses. Put succinctly, in the face of a pandemic, business model innovation is unavoidable. The reasons behind these shifts can be multifaceted: changing the product line to keep operations going, turning threats into opportunities, diversifying customer segments, scoring competitive advantage, boosting reputation, or cutting costs, to name a few. However, not all businesses have the luxury of pivoting their business models overnight.
\end{abstract}

\section{INTRODUCTION}

Data from the Ministry of Cooperative and Small Medium Enterprises (SMEs) show that in the year 2018, there were 64,194,057 SMEs in Indonesia, which employed 116,978,631 workers. Indonesia is dominated by SMEs; they have become the backbone of its economy. They were seriously affected in terms of not only their production and income, but also the amount of energy and work that must be reduced because of this pandemic (Pakpahan, 2020). SMEs have less resilience and flexibility in the face of a pandemic, which is due to several things like low level of digitization, difficulty in accessing the technology, and a lack of understanding about the strategy to survive in the business world (OECD, 2020). SMEs are required to able to adjust themselves because businesses that survive are businesses that are responsive to the development of the times.

During the Covid-19 pandemic, the government issued Government Regulation No. 21 of 2020 on the Limitation of Large-Scale Social Interactions to restrict the movement of people, and they were expected to remain at home if they did not have urgent matters to attend to. It had an impact on those SMEs whose operations were limited because of the reduction of consumers. In the research by Hardilawati (2019) and Setyorini et al. (2019), it was concluded that e-commerce has a positive and significant effect on improving marketing performance and income of SMEs.

SME actors also need to adjust themselves and to condition the sale of goods and products. Improvement of the quality of products and customization of services are required to attract consumers. According to Gary (2013), "the quality of products is their ability to demonstrate overall durability, reliability, accuracy, ease of operation, and repairability". According to Tjiptono (2011), quality of service is the level of excellence that SMEs are expected to show in meeting and conforming to the wishes and expectations of the customers. According to the research by Tripayana and Pramono (2020) and Lestari and R (2019), the quality of products and quality of service significantly impact the purchases of consumers and increase customer satisfaction and customer loyalty.

This research is carried out to answer what SMEs can do and the strategies they can use to be able to maintain their business and be responsive to changes in the business climate during the Covid-19 pandemic. 


\section{METHOD}

This research uses a qualitative method. According to Semiawan (2010), the method of research qualitative is a kind of method of research that is most appropriate to capture the perception of man only with the contact directly and mind open, and through the process of inductive and interaction symbolic humans can know and understand something. The research was conducted in Pekanbaru, with SMEs being the object of research. The data collection technique used in this research is a participatory observation with an exploratory step, that is, using one of the recommended qualitative data collection techniques to obtain descriptive data (Gunawan, 2017). Sources of data used are primary data in the form of observations and secondary data in the form of data collected, processed, and presented by other parties in the form of books and previous research results related to SMEs. After doing participatory observation and conducting research, data associated with the theory, the opinion of the experts, and the results of the previous study were analyzed. In the next section, the results of the findings of the study and recommendations based on the results that could be adopted by SMEs are provided.

\section{DISCUSSION}

Based on the results of observations, the average SMEs, especially those in the culinary field, experienced a decrease in turnover during the Covid-19 pandemic. It was due to the decrease in people's activity outside their home, difficulty in obtaining raw materials due to transport constraints, and decline in people's confidence in products that were prepared outside their homes. SMEs are one of the buttresses the economy because too much supply fieldwork, with their Covid-19's, also began there who do layoffs or laying off employees while for companies/businesses they should be closed while the time.

According to the findings of other researchers based on observation, not all SMEs experienced a drop in turnover of sales or had to shut down their business; there are SMEs that are still stable and that experienced an increase in turnover of sales because they adapt themselves in terms of their products and use marketing strategies to survive. Several things can be done by SMEs, including choosing an open line of products and using a new or renewed system of marketing them, because businesses that survive are the ones that respond well to changes in their environment. Some of the things that can be done by SMEs are as follows:

E-commerce: Research studies by Hanum and Sinarasri (2017) and Ningtyas et al. (2015) show that e-commerce has a positive and significant effect on improving the performance of SMEs. E-commerce yang carried out by SMEs associated with a reduction in the cost of transaction and coordination activities of the economy that is more close between colleagues' business. Technology can be used in business operations to reduce costs and attain company objectives. Hoffman and Fodor (Pradana, 2016) states that SMEs can apply the principles of 4C: connection, creation, consumption, and control. They can improve return on investment (ROI) of the companies, and it can be measured by getting feedback or reviews from the consumer, who can share or recommend the product they used to other people.

The main purpose of using e-commerce by the SMEs is to increase profits, their market share, and the number of areas where sales is conducted; with the use of e-commerce, SMEs can obtain new consumers. SMEs can use e-commerce as a portal not only to sell but also to build relationships; they can also make it a platform for learning. SMEs can also observe how their competitors do sales and adopt their methods.

\subsection{Digital marketing}

Digital marketing is promotional activity and market search through digital media online by utilizing various means such as social networking. (Purwana et al., 2017). Businesspeople use digital marketing to market their products via social media such as Instagram, Facebook, and Twitter. 
Besides, digital marketing can also be done on e-commerce and many other media. The rapid development of technology makes digital marketing a tool that must be understood and studied by SMEs.

Research by Hendrawan et al. (2019) shows that digital marketing has a positive and significant effect on increasing the sales performance of SMEs. 70 percent of employers say digital marketing will become a major platform for all communications in terms of marketing and offline stores will be complementary because of the power of digital marketing to reach more consumers. It is also in line with the research that was carried out by Purwana et al. (2017), who stated that businesspeople must use digital marketing to develop their business. SMEs can also create social media accounts and do promotions regularly to increase trust in the company; they can also increase creativity in marketing.

When using digital marketing, SMEs are forced to always learn and be open to technology, which is rapidly growing. They should also use suitable media and the way of communication that is appropriate to the selected market segment, so that marketing will be more effective and not target the wrong audience.

\subsection{Product and service quality improvement}

Research studies by Sustainable and R (2019) and Tripayana and Pramono (2020) stated that the improvement of the quality of product and quality of service has a positive and significant effect on shaping the satisfaction of consumers and creating customer loyalty. In the future, businesspeople, during pandemics, must pay attention to the dimensions of the quality of their products and improve them; it will increase consumers' confidence.

Product quality is defined as the ability of the product to meet consumer needs and desires (Kotler, Philip, and Armstrong, 2012).

It is important for SMEs to improve of quality of products regularly to meet the needs, desires, and expectations of the consumers. According to Garvin (1998), there are eight dimensions in determining the quality of the product: (1) performance of the product, (2) additional features or attributes that complement and enhance product functionality, (3) reliability or the ability of the products to survive changes in the business environment in the period specified, (4) suitability or how good the products are with respect to the standard that exists in the industry, (5) power resistance or durability of products in terms of technical and economic value or how quickly they can be repaired if problems crop up, (7) product aesthetics, that is, how the product is seen, heard, or felt, and (8) perceptions of product quality, which includes brand reputation and other factors that can influence consumer perceptions.

\subsection{Customer Relationship Marketing (CRM)}

In the future, during a pandemic, SMEs should focus not just on obtaining new customers, but also on retaining existing customers, increasing their satisfaction and loyalty. Loyal customers of SMEs will not buy products from their competitors because they already have confidence in their products. One of the ways the SMEs can survive the decline in business operations is to do customer relationship marketing. Customer relationship marketing is a concept of strategic marketing that seeks to establish a long-term relationship with the customer such as maintaining a solid relationship that is mutually beneficial to both; it can increase sales and create loyal customers. According to research by Farida et al. (2017), customer relationship marketing has a positive and significant effect on improving the marketing performance of SMEs through improving the quality of relationships and entrepreneurial orientation. The better the quality of the relationship between SMEs and their consumers, suppliers, and others, the better their ability to improve their marketing performance. Also, business actors who dare to take risks already have experience in business and are flexible toward business, can increase networks, and foster trust from consumers, so that consumers will be retained. The results obtained in the study by Hardilawati (2019) are different, who stated that CRM has a positive but not significant effect on the improvement of the performance of SMEs. It is because the number people SMEs have is limited, and they cannot carry out CRM to the desired extent. 


\section{CONCLUSION}

The Covid-19 pandemic caused instability in the Indonesian economy, especially in SMEs. SMEs felt the impact immediately in the form of decrease in turnover of sales due to the large-scale social restrictions announced by the government; people were urged to stay at home, which led to a temporary halt in SME business operations. In the future, SMEs must have strategies in place to survive a pandemic and adjust to the conditions they find themselves in.

There are several recommended strategies SMEs can use to survive a pandemic and maintain their business operations: (1) conducting sales via e-commerce because people are now familiar with online shopping, (2) using digital marketing to obtain new customers, (3) providing products and services that are of excellent quality, and (4) conducting customer relationship marketing to increase the confidence of consumers and foster their loyalty.

\section{SUGGESTION}

The suggestions that can be recommended are as follows:

SMEs can adopt strategies that have been mentioned in this study to survive a pandemic; they are expected to adapt themselves to changes in their business environment because businesses that survive a pandemic are the ones that respond well to changes in their environment better in terms of their products, marketing, and sales systems as well as the use of technology that supports the business. The government authorities are expected to continue to provide education in the form of socialization or training to the businesspeople and establish a network of communication for SMEs that can be easily monitored, so that people who are employed in SMEs can keep honing their skills. Also, researchers in the future can expand the study and see the effectiveness of the strategies SMEs can use to survive a pandemic that were formulated in this study.

\section{REFERENCES}

Farida, N., Naryoso, A., \& Yuniawan, A. (2017). Model of Relationship Marketing and E-Commerce in Improving Marketing Performance of Batik SMEs. Journal of Management Dynamics, 8 (1), $20-29$. https://doi.org/10.15294/jdm.v8i1.10408

Garvin, DA (2008). Managing Quality: The Strategic and Competitive Edge. The Free Press. Gary, PK, and. (2013). Marketing Management (14th ed.). Pearson Education Limited.

Gunawan, I. (2017). Qualitative Research Method. In Bumi Aksara (5th ed.).

Hanum, AN, \& Sinarasri, A. (2017). Analysis of the factors that influence the adoption of e-commerce and their influence on the performance of SME. Maksimum Journal, Vol. 1 (No. 1), 1-15.

Hardilawati, WL (2019). Customer Relationship Marketing Model, Innovation, and E-Commerce in Improving SME Marketing Performance in Pekanbaru. Journal of Accounting and Economics, 9 (2), $213-222$.

Hendrawan, A., Sucahyowati, H., Cahyandi, K., Indriyani, \& Rayendra, A. (2019). Influence Digital Marketing Towards Asti Gauri SMES Product Sales Performance in Bantasari Cilacap District. Administration and Secretarial Journal, 4 (1), 53-60.

Kotler, Philip, and Armstrong, G. (2012). Principles of Marketing (15th ed.). London: Pearson. Ningtyas, PK, Sunarko, B., \& Jaryono. (2015). Analysis of Factors That Affect Adoption of E-Commerce And Its Effect On SME Performance, UNSOED Journal, 21, 95-107.

Pakpahan, AK (2020). COVID 19th and Implications For Enterprises Micro, Small, and Medium Enterprises. Journal of Entrepreneurship, 24(4), 1-8.

Purwana, D., Rahmi, R., \& Aditya, S. (2017). Utilization of Digital Marketing For Businesses Micro, Small, and Medium Enterprises (SMEs) in the Village Malaka Sari, Duren Sawit. Journal of Civil Society Empowerment (JPMM), 1 (1), 1-17. https://doi.org/10.21009/jpmm.001.1.01

Setyorini, D., Nurhayati, E., \& Rosmita. (2019). Effect of Transaction Online (e-Commerce) Against Increased Profit SMEs (Study Case SMEs Processing Iron Ciampea Bogor, Jawa Barat). Journal of Management Partners, 3 (5), 501-509.

Tjiptono, Fandy. (2011). Strategi Pemasaran. Edisi 3. Yogyakarta: ANDI.

Tripayana, S., \& Pramono, J. (2020). Quality Product, Service, and Loyalty Customers Where Satisfaction For Variable Intervening in the SME Start-Up Tourism Kombucha Brewing Co., JEMAP Journal, 1(1), $22-45$. 